\title{
KESETARAAN GENDER DALAM PERSPEKTIF ISLAM DAN IMPLEMENKASINYA DALAM HUKUM ISLAM
}

\author{
Anugerah Dharul Ahmadi \\ Program Studi Studi Agama-Agama Fakultas Ushuluddin \\ Universitas Darussalam Gontor,Indonesia
}

\begin{abstract}
Abstrak
Banyak problematika selama ini yang menjadi perbincangan dalam dunia kehidupan sekarang ini. Bahkan problem yang sering timbul adalah masalah antara laki-laki dan perempuan dimana seorang laki-laki selalu menganggap bahwasanya seorang perempuan tak akan pernah mampu menandingi bahkan menyamaratakan apa yang di lakukan oleh laki-laki. Misalnya dalam hal bekerja,berfikir,bahkan meniti karir pun sering menjadi masalah yang sangat sulit untuk di hindari. Disamping itu,perempuan pun tak ingin merasa kalah,tak ingin terlihat lemah di depan laki-laki. Mereka merasa mereka mampu untuk melakukan bahkan melebihi dari apa yang di lakukan oleh laki-laki. Sehingga timbullah sebuah pertikaian diantara kedua golongan tersebut untuk menunjukkan siapa yang lebih layak untuk memenangkan perkelahian tersebut.

Kesetaraan gender akan membawa kita kepada dunia yang beropini bahwasanya semua orang memiliki hak untuk melakukan apa pun tanpa melihat dari jenis kelamin yang di miliki. Seorang perempuan akan terus berusaha untuk menunjukkan bahwasanya dia bukanlah makhluk lemah yang hanya menghabiskan waktunya di rumah untuk melayani suaminya tanpa pekerjaan ataupun karir. Begitu juga laki-laki akan terus memberikan opini bahwa perempuan tak layak akan semua
\end{abstract}


hal itu. Sehingga timbullah permasalahan yang mempermasalahkan siapakah yang akan menjadi pemimpin dalam sebuah perusahaan,negara,organisasi bahkan rumah tangga?.

Dalam tulisan ini kita akan bersama-sama membahas tentang kesetaraan gender tersebut dalam dalam perspektif islam dan bagaimanakah cara untuk mengimplementasikannya dalam hukum islam. Dan apakah pandangan islam dalam hal tentang kesetaraan gender tersebut.

Kata kunci; kesetaraan gender, hukum islam. 


\section{A.PENDAHULUAN}

Salah satu tema sentral sekaligus prinsip pokok ajaran Islam adalah prinsip egalitarian yakni persamaan antar manusia, baik lakilaki dan perempuan maupun antar bangsa, suku, dan keturunan.Hal ini diisyaratkan dalam QS. al-Hujurat: 13

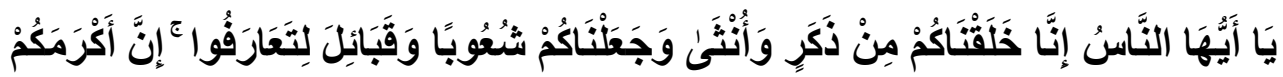

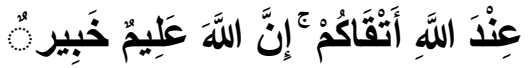

"Hai manusia sesungguhnya kami menciptakan kamu dari seorang laki-laki dan seorang perempuan dan menjadikan kamu berbangsabangsa dan bersukusuku supaya kamu saling kenal-mengenal. Sesungguhnya orang yang paling mulia diantara kamu di sisi Allah adalah orang yang paling bertakwa diantara kamu."

Ayat tersebut memberikan gambaran kepada kita tentang persamaan antara lakilaki dan perempuan baik dalam hal ibadah (dimensi spiritual) maupun dalam aktivitas sosial (urusan karier profesional). Ayat tersebut juga sekaligus mengikis tuntas pandangan yang menyatakan bahwa antara keduanya terdapat perbedaan yang memarginalkan salah satu diantara keduanya. persamaan tersebut meliputi berbagai hal misalnya dalam bidang ibadah. Siapa yang rajin ibadah, maka akan mendapat pahala lebih banyak tanpa melihat jenis kelaminnya. Perbedaan kemudian ada disebabkan kualitas nilai pengabdian dan ketakwaannya kepada Allah swt., Ayat ini juga mempertegas misi pokok al-Qur'an diturunkan adalah untuk membebaskan manusia dari berbagai bentuk diskriminasi dan penindasan, termasuk diskriminasi seksual, warna kulit, etnis dan ikatan-ikatan primordial lainnya. Namun demikian sekalipun secara teoritis al-qur'an mengandung prinsip kesetaraan antara laki-laki dan perempuan, namun ternyata dalam tatanan implementasi seringkali prinsip-prinsip tersebut terabaikan.

Konteks khalifatullâh fî̀ al-ardh secara terminologis, berarti "kedudukan kepemimpinan". Ini berarti bahwa semua manusia, baik laki-laki maupun perempuan diamanatkan menjadi pemimpin. Namun demikian, bila dicermati lebih lanjut ternyata ada nash Qur'an maupun hadis yang kelihatannya berdimensi 
maskulin, dan secara sepintas menyorot masalah misogoni.Sementara ajaran Islam, diyakini sebagai rahmat untuk semua manusia tanpa membedakan jenis kelamin. ${ }^{1}$

Dewasa ini agama sering dituduh sebagai sumber terjadinya ketidak adilan dalam masyarakat, termasuk ketidak adilan relasi antara laki-laki dan perempuan yang sering disebut dengan ketidak adilan gender. Gender adalah jenis kelamin bentukan yang dikonstruksi oleh budaya dan adat istiadat, seperti laki-laki kuat, berani, cerdas, menguasai, sedangkan perempuan itu lemah, penakut, kurang cerdas (bodoh), dikuasai dll. Isu gender menguat ketika disadari bahwa perbedaan gender antara manusia laki-laki dan perempuan telah melahirkan ketidak adilan dalam berbagai bentuk seperti marginalisasi atau pemiskinan ekonomi, subordinate atau anggapan tidak penting dalam urusan politik, stereotype atau pencitraan yang negatif bagi perempuan Citra perempuan yang dimaksud hanya bergelut 3R (dapuR, sumuR,kasuR), kekerasan, dan double burden (beban ganda) terhadap perempuan yang bermuara pada perbuatan tidak adil yang dibenci oleh Allah swt. ${ }^{2}$

Bahkan sempat kita mendengar bahwasanya pada masa sebelum islam (masa jahiliyah), martabat seorang perempuan sangat rendah bahkan bagi mereka melahirkan seorang anak perempuan adalah aib bagi keluarga mereka. Maka siapaun yang melahirklan anak perempuan pada masa itu anak perempuan itu akan langsung di bunuh atau di kubur hidup-hidup. Begitulah fakta yang kita dapatkan selama ini.

Hal tersebut juga menjadi awal dimana perempuan selalu memperjuangkan harkat serta martabatnya demi melangsungkan kehidupannya dan tak ingin diperlakukan sepertimana yang telah dilakukan oleh orang-orang jahiliyah dulu. Mereka merasa bahwasanya mereka juga layak untuk mempunyai karir seperti lakilaki.

\footnotetext{
${ }^{1}$ H. Abd. Muin, Fiqih Siyasah; Konsepsi Kekuasaan Politik dalam al-Qur'an, (Cet. I; Jakarta: PT. RajaGrafindo persada,1992) hal.114

${ }^{2}$ Sarifa Suhra, "Kesetaraan gender dalam perspektif Al-qur'an dan implikasinya dalam hukum islam" Jurnal Al-Ulum

Volume. 13 Nomor 2, Desember 2013 Hal 373-394
} 


\section{B.MAKNA GENDER}

Istilah dari gender menimbulkan berbagai penafsiran yang berbeda-beda, dimana kata gender dalam istilah bahasa Indonesia berasal dari bahasa inggris "gender" diartikan sebagai jenis kelamin. ${ }^{3}$ Dan mengacu dari pendapat yang diberikan oleh Mansour Faqih, memberikan arti bahwa gender merupakan suatu sifat yang memang melakta pada diri perempuan dan juga pada diri laki-laki di mana dapat di lakukan konstruksi baik dalam kultural dan juga dalam sosial. Sebagai contoh dalam diri perempuan dipandang dan dilihat sangatlah emosional, juga cantik dan juga lemah dan juga sebagainya. Sementara itu dalam diri pihak laki-laki lebih pandang sangatlah kuat, dan juga rasional, serta jantan dan perkasa, dan tidak boleh cengeng atau juga menangis. Sifat dan ciri yang dapat dipertukarkan dan adanya perubahan dari ciri dan sifat dapat terjadinya dari waktu ke waktu dan juga dari tempat ke tempat yang lain, bahakn tidak menutup kemungkinan dapat terjadi di dalam kelas masyarakat yang berbeda. ${ }^{4}$

Kata gender dapat diartikan sebagai peran yang dibentuk oleh masyarakat serta perilaku yang tertanam lewat proses sosialisasi yang berhubungan dengan jenis kelamin perempuan dan laki-laki. Ada perbedaan secara biologis antara perempuan dan laki-laki-namun kebudayaan menafsirkan perbedaan biologis ini menjadi seperangkat tuntutan sosial tentang kepantasan dalam berperilaku, dan pada gilirannya hak-hak, sumber daya, dan kuasa. Kendati tuntutan ini bervariasi di setiap masyarakat, tapi terdapat beberapa kemiripan yang mencolok. Misalnya, hampir semua kelompok masyarakat menyerahkan tanggung jawab perawatan anak pada perempuan, sedangkan tugas kemiliteran diberikan pada laki-laki. Sebagaimana halnya ras, etnik, dan kelas, gender adalah sebuah kategori sosial yang sangat menentukan jalan hidup seseorang dan partisipasinya dalam masyarakat dan ekonomi. Tidak semua masyarakat mengalami diskriminasi berdasarkan ras atau etnis, namun semua masyarakat mengalami diskriminasi berdasarkan gender-dalam bentuk kesenjangan dan perbedaan-dalam tingkatan

${ }^{3}$ M. Echols John dan Sadily, H. (1983). Kamus Inggris Indonesia, Jakarta: Gramedia, cet XII, h. 265

4 Fakih, M. (2007). Analisis Gender dan Transformasi Sosial, Yogyakarta: Pustaka Pelajar, h. 8-9 
yang berbeda-beda. Seringkali dibutuhkan waktu cukup lama untuk mengubah ketidakadilan ini. Suasana ketidakadilan ini terkadang bisa berubah secara drastis karena kebijakan dan perubahan sosial-ekonomi

\section{C.DEFINISI KESETARAAN GENDER}

Pengertian kesetaraan gender merujuk kepada suatu keadaan setara antara lakilaki dan perempuan dalam pemenuhan hak dan kewajiban.

Diskriminasi berdasarkan gender masih terjadi pada seluruh aspek kehidupan, di seluruh dunia. Ini adalah fakta meskipun ada kemajuan yang cukup pesat dalam kesetaraan gender dewasa ini. Sifat dan tingkat diskriminasi sangat bervariasi di berbagai negara atau wilayah. Tidak ada satu wilayah pun di negara dunia ketiga di mana perempuan telah menikmati kesetaraan dalam hak-hak hukum, sosial dan ekonomi. Kesenjangan gender dalam kesempatan dan kendali atas sumber daya, ekonomi, kekuasaan, dan partisipasi politik terjadi di mana-mana. Perempuan dan anak perempuan menanggung beban paling berat akibat ketidaksetaraan yang terjadi, namun pada dasarnya ketidaksetaraan itu merugikan semua orang. Oleh sebab itu, kesetaraan gender merupakan persoalan pokok suatu tujuan pembangunan yang memiliki nilai tersendiri.

Kesetaraan gender akan memperkuat kemampuan negara untuk berkembang, mengurangi kemiskinan, dan memerintah secara efektif. Dengan demikian mempromosikan kesetaraan gender adalah bagian utama dari strategi pembangunan dalam rangka untuk memberdayakan masyarakat (semua orang)perempuan dan laki-laki-untuk mengentaskan diri dari kemiskinan dan meningkatkan taraf hidup mereka.

Pembangunan ekonomi membuka banyak jalan untuk meningkatkan kesetaraan gender dalam jangka panjang. Agenda Tujuan Pembangunan Berkelanjutan memiliki makna yang penting karena setelah diadopsi maka akan dijadikan acuan secara global dan nasional sehingga agenda pembangunan menjadi lebih fokus. Setiap butir tujuan tersebut menjunjung tinggi Hak Asasi Manusia (HAM) dan untuk mencapai kesetaraan gender dan pemberdayaan perempuan, baik tua maupun muda. 
Di bidang pergaulan hidup, masyarakat jahiliyah mempunyai hukum perkawinan, hukum waris, dagang, dan lain-lain. Hukum perkawinan dan waris Jahiliyah meletakkan wanita sebagai tidak breharga. Pria boleh menikahi wanita sebanyak-banyaknya tanpa mas kawin dan tanpa batas maksimum. Wanita tidak mempunyai hak menerima bagian warisan harta orang tua atau keluarganya yang meninggal, bahkan wanita menjadi harta warisan. Maka ide kewarisan dalam islam, memberi bagian warisan bagi wanita, kalau tidak dipandang layak sama besarnya dengan bagian pria, setidaknya seperduanya. Gambaran tersebut menujukkan bahwa secara realitas kesejarahhyan Islam telah mendekonstruksi kebiasaan yang berlaku dari tradisi hukum Arab jahiliyah dengan pendekatan yang lebih humanis terhadap posisi perempuan dalam kontek hukum keluarga. Dalam beberapa kasus sejak kemunculan ide memberikan bagian warisan bagi perempuan dari ajaran Islam itu, telah menimbulkan reaksi yang keras dari para tokoh-tokoh Arab Pra-Islam yang memegang teguh tradisi Jahiliyahnya dengan memusuhi bahkan menyatakan perang terhadap Nabi Muhammad saw, karena dianggap telah berani menodai kultur dan tradisi nenek moyang mereka, dengan memberikan hak waris bagi perempuan. ${ }^{5}$

\section{PERAN PEREMPUAN DALAM PENDIDIKAN ISLAM}

Dalam banyak perbincangan publik pada era modern ternyata perjuangan persamaan gender yang telah lama didengungkan, secara realitas menujukkan bahwa peran perempuan dalam perspektif persemaan hak dan keddudukan dengan laki-laki telah sedemikian maju dan berkembang. Hal ini tidak bisa dilepaskan dari adanya kesadara dari kaum perempuan itu sendiri mengenai arti penting pendidikan bagi masa depan umat manusia khusunya perempuan muslim, dalam mengahadapi persaingan kerja dan karir yang setara dengan laki-laki.

\footnotetext{
${ }^{5}$ Zainal Abidin," Kesetaraan Gender dan Emansispasi Perempuan Dalam Pendidikan Islam", Jurnal Tarbawiyah, Vol. 12, No. 01, Edisi Januari - Juni 2015
} 
Dalam konteks sejarah paling tidak peran perempuan di bidang pendidikan telah dilakukan oleh isteri Nabi Muhammad SAW, seperti peranan siti Aisyah RA, yang terkenal kan kecerdasannya dan jasanya dalam meriwayatkan beberapa hadits. Kemudian pada masa Dinasti Fatimiyyah di Mesir, yang merepresentasikan kekuatan politis representasi gender dalam politik Islam. Dinasti ini tercatat sebagai Dinasti yang mengembangkan kajian KeIslaman madzhab Syiah di Mesir dengan mendirikan Jami' al-Azhar sebagai cikal bakal Universitas Al-Azhar menjadi pusat pengembangan pendidikan dan keilmuan pada masanya.

Azyumardi Azra mensinyalir bahwa perhatian ulama tentang peran penting perempuan Islam dalam bidang pendidikan dan keilmuan Islam telah digambarkan secara menarik oleh beberapa ulama terkenal. Sebagaimana yang ditulis oleh sejarawan Muslim, al-Khatib al-Baghdadi dalam kamus biografinya berjudul Tarikh Baghdad, memuat biografi sejumlah ulama perempuan. Begitu juga alSakhawi menulis beberapa kamus biografi tokoh-tokoh abad ke-15 terutama alDaw' al-Lami', khusus tentang perempuan yang diberi judul Kitab al-Nisa' . Dalam terakhir diberikan biografi sekitar 1075 perempuan, 411 orang diantaranya mempunyai pendidikan agama yang tinggi. ${ }^{6}$ Bahkan Salabi memberikan data tentang jumlah ulama perempuan yang mencapai 1543 dalam kitan alIshabah fi Tamyiz al-Shahabah karya Ibnu Hajar. Begitu dalam kitab Tahzibal-Asma' karya an-Nawawi menyebut bahwa jumlah ulama perempuan cukup besar pada era klasik Islam. ${ }^{7}$

Dalam konteks ke-Indonesiaan sebenarnya ulama-ulama perempuan yang konsens dan mempunyai perhatian terhadap pendidikan bisa disebutkan misalnya di kerajaan Aceh pernah diperintah beberapa Sultanah, yang mempunyai kekuatan politis juga kepakaran di bidang ilmu agama Islam, dan perhatian yang besar terhadap keberlangsungan agama Islam melalui jalur pendidikan Islam dan dakwah Islam. Pada abad ke-20 muncul beberapa aktifis pendidikan Islam seperti Nyai Ahmad Dahlan, dan beberapa Nyai (ulama Perempuan) yang berkiprah dalam

\footnotetext{
${ }^{6}$ Azyumardi Azra, "Membongkar Peranan Perempuan dalam bidang Keilmuan", dalam Kepemimpinan Perempuan Dalam Islam, ( Jakarta: JPPR, 1999), h. 70.

${ }^{7}$ Azyumardi Azra, h.71
} 
pesantren-pesantren tradisional. Bahkan tokoh emansipasi perempuan di Indonesia RA. Kartini menurut penelitian terakhir, beliau juga pernah nyantri pada ulam terkenal di Jawa Tengah, yang juga turut menginspirasi kesadarannya untuk memperjuangkan pendidikan bagi kaum perempuan. Di samping tentunya interaksi Kartini dengan teman-temanya di Belanda. Yang menarik adalah temuan bahwa kartini sebagai bangsawan perempuan Jawa yang beragama Islam, juga mendapat pendidikan pesantren, dan dianggap berakakar kuat dalam kepribadiannya dalam mengangkat derajat perempuan di bidang pendidikan. Dalam beberapa situs hasil penelitian mengengungkapkan bahwa RA. Kartini pernah belajar agama Islam (nyantri) kepada Kyai Soleh Darat, namun hal itu tidak pernah ditulis dalam sejarah biografi Kartini, karena sengaja digelapkan oleh Orientalis. Interaksi Kartini dengan Kyai Soleh Darat tertarik untuk menerjemahkan al-Qur'an ke dalam bahasa Jawa atas insprirasi RA Kartini. ${ }^{8}$

\section{E.PANDANGAN ISLAM TERHADAP KESETARAAN GENDER}

Kesetaraan sempurna laki-laki dan perempuan di dalam Islam, sebagai manusia, perempuan punya persamaan sempurna dengan laki-laki, sama-sama bisa beristiqomah karena kebajikan tidak berjenis kelamin dan juga kejahatan tidak berjenis kelamin, setara dalam independen dalam mempertanggungjawabkan perbuatannya, sama-sama mendapatkan pendidikan, setara dalam kewajiban menuntut ilmu baik yang berupa fardu ain dan fardu kifayah, sama-sama diwajibkan terlibat aktif dalam dakwah, setara dalam melakukan transaksi secara mandiri.

Status perbedaan laki-laki dan perempuan, perbedaan yang ada menjadikan sumber perdamaian untuk saling melengkapi di dalam keluarga, perbedaan fisik juga menjadikan untuk saling membantu satu sama lain, perbedaan mendorong tanggung jawab pengabdian didalam kehidupan rumah tangga, perbedaan itu

\footnotetext{
${ }^{8}$ Syahrul Amar," Perjuangan Gender Dalam Kajian Sejarah Wanita Indonesia Pada Abad XIX,Jurnal", Fajar Historia,Volume 1 Nomor 2, Desember 2017, hal. 105-119
} 
kesempurnaan untuk dapat mendorong masing-masing untuk saling merindukan, psikologi perempuan yang lebih lembut memungkinkan lebih sempurna dalam mendidik dan membesarkan anak-anaknya, sehingga terlihat perbedaan menentukan perbedaan tugas dan tanggung jawab antara laki-laki dan perempuan. Seperti yang disebutkan dalam surat An-Nisa ayat 32 yang artinya bebrbunyi sebagai berikut :

"Dan janganlah kalian iri hati terhadap apa yang dikaruniakan Allah kepada sebagian kalian lebih banyak dari sebagian yang lain. (Karena) bagi orang lakilaki ada bagian dari apa yang mereka usahakan, dan bagi para wanita (pun) ada bagian dari apa yang mereka usahakan, dan mohonlah kepada Allah sebagai dari karunia-Nya Sesungguhnya Allah Maha mengetahui segala sesuatu."

Seperti ayat di atas bahwasanya tidak ada perbedaan antara laki-laki dan perempuan kecuali ketakqwaan mereka dalam menjalankan perintah Allah swt dan mejahui larangannya. Semua dianngap sama tidak ada perbedaan hanya dilihat dari amalan mereka selama di dunia lah yang akan membedakan derajat keduanya di hadapan Allah swt. 